\title{
Utilisation of Pervious Concrete for Removal of Heavy Metals in Contaminated Waters: Opportunities and Challenges
}

\author{
Ayanda N. Shabalala1 \\ ${ }^{1}$ University of Mpumalanga, School of Biology and Environmental Sciences \\ P/Bag x 11283, Mbombela, South Africa \\ Ayanda.Shabalala@ump.ac.za
}

\begin{abstract}
While a number of studies have been done on the use of pervious concrete for stormwater runoff management and improvement of water quality with respect to total suspended solids, phosphorous, and nitrogen, hardly any articles have summarized the recent progress on the use of pervious concrete for the removal of heavy metals from aqueous solutions. This work aims to provide a review of current knowledge relevant to the use of pervious concrete in the remediation of water containing high metal concentrations. In addition, the challenges, limitations, and prospects of pervious concrete applications in heavy metal removal from polluted water are discussed. The potential use of pervious concrete as a low cost reactive barrier system for the removal of heavy metals present in polluted waters is a promising alternative to current treatment methods.
\end{abstract}

Keywords: Pervious concrete, polluted waters, pollutant removal mechanisms, field performance, opportunities, and challenges

\section{Introduction}

Pervious concrete has attracted more attention in the concrete industry in pursuit of environmental protection and sustainability [1]. Also referred to as porous or permeable concrete, pervious concrete is a porous medium that comprises cement, water, and a single-size aggregate (Fig.1). Pervious concrete has interconnected voids that are typically in a range of 15 to $30 \%$ pore volume which allows fluids to pass easily from the surface to the underlying layers [2]. Shang \& Sun [3] defined pervious concrete as a unique type of concrete made using a carefully controlled amount of cement paste to coat and bind the uniformly sized coarse aggregates and containing little or no fine aggregates to form a system of interconnected voids of a high porosity that can drain water quickly. Pervious concrete hydraulic performance is directly related to the resulting porosity of the mixture. Higher porosity mixtures have better flow properties but lower strength and durability. The absence of fine aggregates in pervious concrete creates pores that help to store stormwater within them and to reduce surface runoff quantity [4]. Pervious concrete is usually made up of aggregate sizes in the range of $19-9.5 \mathrm{~mm}$. In other studies, however, coarse aggregates of size $9.5-2.36 \mathrm{~mm}$ have been used, with the aim of increasing the strength property. The water to cement ratio is usually varied over the range of $0.28-0.40$, and the aggregate to cement ratio is typically varied from $4: 1$ to as high as $6: 1[5,6]$.

Pervious pavements are commonly used in driveways, parking lots, sidewalks, and pathways to minimize stormwater related flooding by allowing the infiltration of surface runoff into the pavement, reducing the risk of flash flooding caused by stormwater [7]. Pervious concrete can function as a pollution sink, because of its particle retention capacity during filtration. Contaminants such as heavy metals and organic compounds are absorbed into the internal concrete body and are eliminated from the runoff [8]. The high porosity of the concrete leads to good infiltration and air exchange rates [9]. Other potential benefits of using this type of pavement include recharging groundwater, saving water by recycling, and prevention of pollution. Reductions in suspended solids, biochemical oxygen demand, chemical oxygen demand, and ammonia levels in surface run-offs demonstrate the high treatment efficiency of pervious pavement systems [10]. It can also lead to a reduction in oil, grease, and petroleum products, from the water effluent drained through pervious concrete. Furthermore, pervious concrete is capable of removing different kinds of bacteria or micro-organisms such as faecal coliforms, micrococcus leteus, etc. that may easily be found in contaminated water systems [11]. 


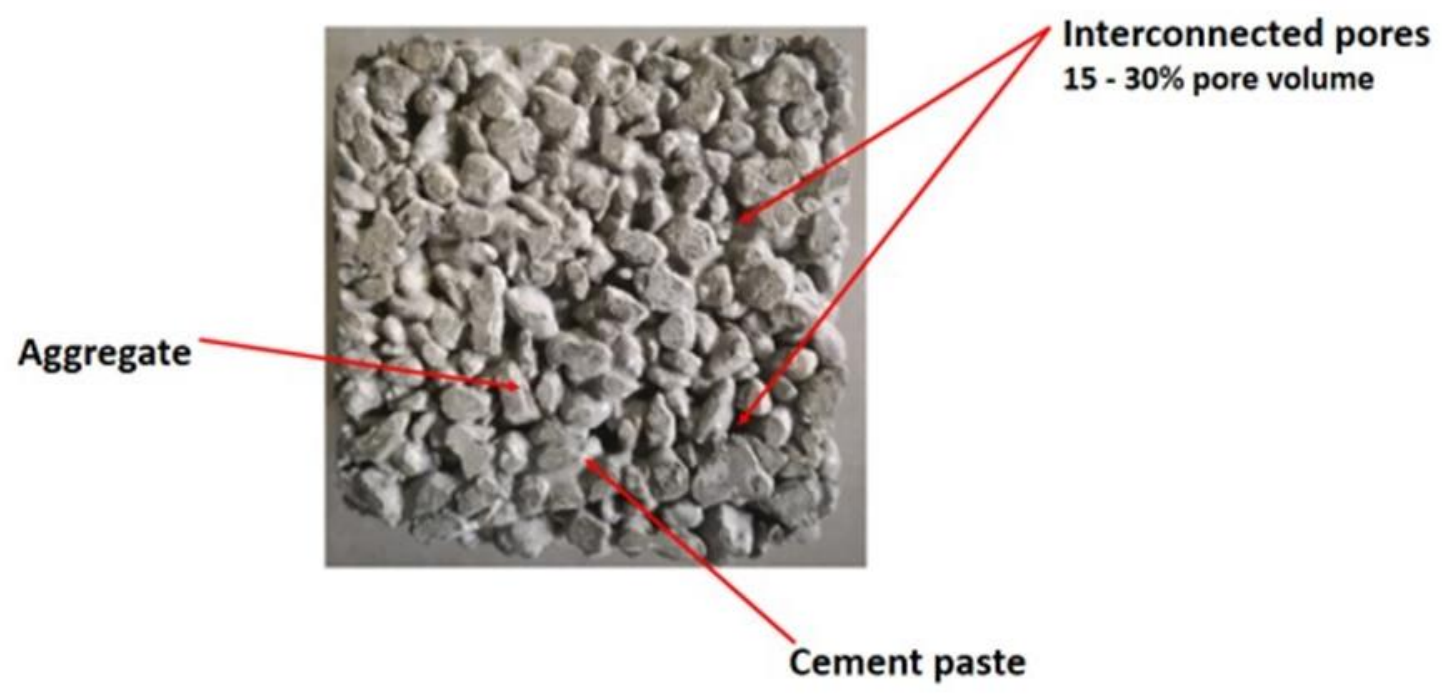

Figure 1. Pervious concrete pore structure

\section{Discussion}

\subsection{Heavy Metal Removal In Polluted Waters Using Pervious Concrete}

Application of porous concrete has been shown to improve the water quality of urban runoff such as reducing organic and metal contaminants, suspended solids, and chemical oxygen demand (COD). Runoff water passing through porous pavements contains lower pollutant loads than those from a reference catchment due to the accumulation of metallic micropollutants from runoff water on the surface of the pervious pavement [12]. Ekolu et al. [10] developed a pervious concrete system for potential use as a Permeable Reactive Barrier (PRB) for treatment of Acid Mine Drainage (AMD). Pervious concrete mixtures of various water/cement ratios $0.50,0.40,0.35,0.30,0.27$ and cement contents $300,360,380,400 \mathrm{~kg} / \mathrm{m} 3$ were prepared. Dolomite and granite aggregate types of size $9.5 \mathrm{~mm}$, were employed. The concrete PRB treatment led to the effective removal of major metals from the AMD. The treatment reduced the metals in the AMD by $30 \%$ sulfate, $99 \%$ iron, 50-83\% manganese, $85 \%$ calcium, and $30 \%$ total dissolved solids.

Shabalala et al. [13] investigated the potential use of pervious concrete as a low cost reactive barrier system for the removal of heavy metals present in polluted mine water. Pervious concrete mixtures consisting of Portland cement CEM I $52.5 \mathrm{R}$ with or without $30 \%$ fly ash (FA) were prepared at a water-cementitious ratio of 0.27 then used to make cubes which were employed in the reactor columns. The study revealed that pervious concrete can be effective in treating acidic water by raising its $\mathrm{pH}$ value and removing most of the undesirable contaminants including iron, aluminium, zinc, sodium, magnesium and manganese. When acidic AMD is made to flow through pervious concrete, its acidity is neutralised and $\mathrm{pH}$ is raised to high levels between 9 and 12. At this range of $\mathrm{pH}$, most heavy metals precipitate out of solution as metal hydroxides.

Zhang et al. [14] investigated the long-term removal of heavy metals in three different porous pavements referred to as Porous Asphalt (PA), Hydrapave (HP), and Permapave (PP) in accelerated laboratory experiments conducted over a period of 26 years. The study confirmed that a porous pavement is good in removing heavy metals including $\mathrm{Pb}, \mathrm{Al}, \mathrm{Fe}, \mathrm{Zn}, \mathrm{Mn}$, and $\mathrm{Cu}$. All three pavements were most effective in removing $\mathrm{Pb}(84 \pm 14 \%)$, $\mathrm{Al}(79 \pm 13 \%), \mathrm{Fe}(77 \pm 13 \%)$, and less effective for the removal of $\mathrm{Cu}(68 \pm 19 \%, \mathrm{Zn}(66 \pm 20 \%)$ and $\mathrm{Mn}(35 \pm 35 \%)$. The differences in removal levels of heavy metals, can be explained by their affinity to particulates, for instance $\mathrm{Pb}, \mathrm{Al}$ and $\mathrm{Fe}$ are easily attached to sediments in stormwater and hence can be readily retained when filtering through porous pavements. These retained metals can form stable complexes via surface complexation reactions. $\mathrm{Cu}$ and $\mathrm{Zn}$ are largely present in dissolved form and their retention by porous pavements usually occurs through weak processes such as ion exchange. Mn also has a good attachment with sediments or organic matter in stormwater. In general, the removal process of $\mathrm{Mn}$ can be in the form of manganese oxides.

A study by Nnadi et al. [15] showed that pervious pavement systems have the capability to recycle stormwater to a quality that meets the chemical standards for use in agricultural irrigation. The study showed that stormwater recycled in 
pervious pavement system had low levels of $\mathrm{Al}, \mathrm{Mn}, \mathrm{Fe}, \mathrm{Ni}, \mathrm{Cd}, \mathrm{Pb}, \mathrm{Zn}, \mathrm{As}, \mathrm{B}, \mathrm{V}$ and Mo and therefore did not pose a risk of toxicity when used for irrigation. In addition, Nnadi et al. [15] reported that when water is being recycled in pervious pavement systems for irrigation, there is a potential benefit of nutrient availability in recycled water for plants.

Lee et al. [16] studied pervious concrete pavements for the removal of pollutants in acid rain, seawater or waste lubricating oil. The results showed that pervious concrete significantly improved pollutant removal and water purification. Pervious concrete systems were reported to have reduced the amount of total nitrogen by $37-95 \%$ as well as reducing the total phosphorous by 66-95\%.

According to Luck et al. [17], pervious concrete could be a promising component in the treatment of wastewater from animal production facilities. Laboratory tests were conducted on samples of pervious concrete made from river gravel and limestone aggregate sources. Water was filtered through composted beef cattle manure and bedding (compost) that was placed on top of the pervious concrete. Filtering the compost effluent through pervious concrete led to significant reductions in total nitrogen, soluble phosphorus, and total phosphorus. The pervious concrete was effective in solid/ liquid separation by retaining 92-97\% solid material as the water was passed through the compost and pervious concrete. Soluble phosphorus (SP) reduction may have occurred due to available $\mathrm{Ca}$ or $\mathrm{Mg}$ in the pervious concrete which, given the high $\mathrm{pH}$, could have allowed $\mathrm{P}$ to precipitate as $\mathrm{Ca}$ or $\mathrm{Mg}$ phosphates instead of SP. Another mechanism responsible for the reduction of analytes in the effluent could also be due to absorption or retention of effluent water in the pervious concrete. The pervious concrete was able to absorb effluent water from the compost, which may have been a major factor in the reduction of total nutrient loads from the system.

Haselbach et al. [18] explained that when ordinary portland cement (OPC) is used to make concrete, the compounds that result include hydroxide species especially calcium hydroxide. In the interconnected flow channels throughout pervious concrete, there are also carbonates in addition to the hydroxide species. At the surface due to carbonation occurs from the carbon dioxide in the atmosphere. Dissolved metals are likely removed from the solution due to complexation and solids formation with the hydroxides $\left(\mathrm{OH}^{-}\right)$and carbonates $\left(\mathrm{CO}_{3}{ }^{2-}\right)$ that are attached to calcium in the concrete, as given in Eqs. (1) and (2).

$\mathrm{Mex}++2 \mathrm{OH}^{-} \rightarrow \mathrm{Me}(\mathrm{OH}) \mathrm{x}(\mathrm{s})$

Where $\mathrm{Me}$ is the metal $\mathrm{Al}, \mathrm{Zn}, \mathrm{Fe}, \mathrm{Cu}, \mathrm{Pb}$ etc. of valency, $\mathrm{x}$.

$\mathrm{Mex}++\mathrm{CO}_{3}{ }^{-} \rightarrow \mathrm{MeCO}_{3}(\mathrm{~s})$

Where $\mathrm{Me}$ is the metal $\mathrm{Ca}, \mathrm{Zn}, \mathrm{Cu}$ etc. of valency, $\mathrm{x}$.

Removals of metals by pervious concrete occur through absorption, adsorption, precipitation, co-precipitation, and diffusion. At low concentrations, adsorption is the primary source of removal. Precipitation and co-precipitation are likely the primary initial removal mechanisms at high concentrations of metals [19]. Permeable concrete typically contains coarse aggregate bound by cement paste. Portland cement hydration produces highly alkaline conditions of $\mathrm{pH} 12.0$ and causes metals in solution to precipitate or sorb with the cement hydration products such as calcium-silica-hydrate (CSH) gel. The aggregate and cement contain available reactive calcium including either calcium carbonate, calcium hydroxide (portlandite), or calcium silica hydrate gel (CSH). The adsorption of heavy metals on cement and limestone is caused by the displacement of calcium ions at the material's surface [19].

In a recent study, Sephton and Webb [20] conducted leach column testing of the neutralisation of AMD by hydrated Portland cement and showed that the cement completely neutralised all the acidity and caused most of the dissolved metals ( $\mathrm{Fe}, \mathrm{Al}, \mathrm{Mg}, \mathrm{Si}, \mathrm{Cu}, \mathrm{Mn}$, and $\mathrm{Zn}$ ) in the AMD to precipitate. This was due to the dissolution of alkaline phases within the cement, such as portlandite, hydrated calcium silicate and aluminate phases, and later ettringite and thaumasite. The formation of higher amounts of ettringite and thaumasite in AMD-leached cement caused expansion and cracking, allowing deeper penetration of AMD and better long-term neutralisation. The study concluded that cement may be a viable method for controlling acid mine drainage generation from waste rock dumps. 


\subsection{Field Application Of Pervious Concrete Systems}

In North Carolina (US), four permeable pavements were constructed and monitored to determine their effectiveness in reducing runoff quantity and improving water quality for 26 months [21]. The water quality results showed that the concentrations of total Kjeldahl nitrogen, ammonia, total phosphorus, and zinc were significantly reduced by the permeable pavements. The results also showed no significant changes in nitrate, nitrite, or total suspended solids.

Trace metals commonly found in urban runoffs such as lead, copper, cadmium, and zinc may be caused by particulates from buildings, vehicle tire wear, and atmospheric pollution [12]. Brattebo and Booth (2003) conducted an experiment that evaluated the performance of permeable pavement systems from the perspective of water quality after 6 years of daily use. They found that the infiltrated stormwater had copper and zinc concentrations below detectable levels. This is comparable to the study by Haselbach et al. [18] who investigated the effectiveness of pervious concrete in removing dissolved zinc and copper contaminants from stormwater runoff. The results indicated $90 \%$ and $87 \%$ concentration decreases for $\mathrm{Zn}$ and $\mathrm{Cu}$ respectively. The study concluded that the pervious concrete pavement system effectively removes dissolved zinc and copper due to the chemical and physical characteristics of the concrete such as the high $\mathrm{pH}$, the carbonate species, the high surface areas for sorption in the tortuous channels, and the physical capture of water in the interconnected pores with subsequent evaporation and precipitation. The likely processes for the removal of dissolved copper and zinc by pervious concrete are surface adsorption forming various complexation species, diffusion, and additional complexation species development in the concrete matrix.

A study by Liu and Borst [22] reported similar results. In their paper, six years of monitoring data for 22 metals in the infiltrate from three permeable pavements, i.e. the permeable interlocking concrete pavers (PICP), pervious concrete (PC), and porous asphalt (PA) showed that in the majority of samples tested, the concentration of barium, chromium, copper, manganese, nickel, zinc, arsenic, cadmium, lead, and antimony from all three permeable pavements met both the groundwater effluent limitations (GEL) and maximum contaminant levels (MCL). The concentration of aluminium and iron in more than 90\% of PC infiltrates samples met the GELs. Possible pollutant removal mechanisms in permeable pavements include filtration, adsorption, desorption, and physical capture of metals in the pervious concrete interconnected pores.

In the study by Gilbert and Clausen [23], the stormwater runoff qualities from replicated asphalt, permeable paver, and crushed-stone driveways were compared. It was found that runoff from permeable paver driveways contained significantly lower concentrations of pollutants than runoff from asphalt and crushed stone driveways. $\mathrm{Cu}, \mathrm{Pb}$, and $\mathrm{Zn}$ concentrations in runoff from permeable paver were lower than the acute aquatic toxicity threshold of 13, 65, and $120 \mathrm{mg} / \mathrm{L}$, respectively. These findings are comparable to a study by Fassman et al [24], who monitored a discharge from a $200 \mathrm{~m}^{2}$ permeable modular concrete paver test section concurrently with an adjacent reference conventional asphalt section between 2006 and 2008 in Auckland, New Zealand. It was found that the permeable modular pavement (PMP) underdrain water quality had consistent total suspended solids (TSS), zinc, and copper mean concentrations that were less than the reference asphalt runoff. An average $70 \%$ and $90 \%$ reduction in copper and zinc, respectively, was achieved when using the permeable modular pavement. Sorption of $\mathrm{Cu}$ and $\mathrm{Zn}$ to the Permeable modular pavement was suggested to be the main removal mechanism.

The impact of porous pavements on soil chemistry was investigated in Christchurch, New Zealand [25]. The experiment was carried out using four different pavement treatments: impervious concrete pavement, impervious concrete pavement with a gravel base, porous concrete pavement, and porous concrete pavement with a gravel base. The study found that concentrations of $\mathrm{Ca}, \mathrm{Fe}, \mathrm{Mg}$, and $\mathrm{K}$ were lower beneath pavements incorporating a gravel base. Porous pavements decreased $\mathrm{Al}$ and $\mathrm{Fe}$ concentrations but increased $\mathrm{K}$ and $\mathrm{Na}$. Higher soil $\mathrm{pH}$ beneath the porous pavement, affected mineral solubility, reducing the soil concentration of $\mathrm{Al}, \mathrm{Fe}$, and $\mathrm{Mg}$ while increasing the $\mathrm{Na}$ concentration beneath the pavements.

Wang et al. [26] installed two in-situ permeable reactive barriers (PRBs), comprising of limestone and crushed concrete, at a landfill in Florida, USA, to remediate groundwater containing high concentrations of manganese and iron. The study found that PRBs significantly removed dissolved Fe and $\mathrm{Mn}$ from groundwater. Iron was removed from influent water at average rates of $91 \%$ and $95 \%$ for the limestone and crushed concrete PRBs respectively, during the first year of the study. The performance of the PRBs declined after 3 years of operation, with Fe removal efficiency decreasing to $64 \%$ and $61 \%$ for limestone and concrete PRBs, respectively. Precipitation of Fe and Mn as carbonate and hydroxide minerals was believed to be the dominant removal mechanism. Soluble Fe and $\mathrm{Mn}$ can be removed from the solution via sorption onto reactive media and precipitation of solid species. Metal carbonate precipitates $\left(\mathrm{FeCO}_{3}, \mathrm{MnCO}_{3}, \mathrm{CaFe}\left(\mathrm{CO}_{3}\right)_{2}\right)$ and metal hydroxides $\left(\mathrm{Fe}(\mathrm{OH})_{2}, \mathrm{Mn}(\mathrm{OH})_{2}\right)$ were the main precipitation products. The study concluded that the short time frame of effectiveness 
relative to the duration of a full-scale remediation effort may limit the applicability of these systems at some landfills because of the construction costs required.

A pilot scale study using zeolite or basalt as bed material in permeable pavement systems (PPS) removed 41-72\%, $6774 \%, 38-43 \%, 61-72 \%, 63-73 \%$ of $\mathrm{Cd}, \mathrm{Cu}, \mathrm{Ni}, \mathrm{Pb}$, and $\mathrm{Zn}$, respectively, from synthetic stormwater over a period of $80 \mathrm{~h}$. The total volume of stormwater that passed through the PPS was equivalent to runoff in 10 years of rainfall in Sydney, Australia. The study showed that the zeolite or basalt based PPS did not remove sufficient amounts of $\mathrm{Cd}, \mathrm{Cu}, \mathrm{Ni}, \mathrm{Pb}$, and $\mathrm{Zn}$ from synthetic stormwater that passed through the PPS. The concentrations of metals in the effluent did not meet water quality standards of fresh and marine waters. An addition of a horizontal filter column containing a titanate nano-fibrous (TNF) material and granular activated carbon (GAC) to the zeolite based PPS, removed 77\% Ni and 99-100\% of all the other metals. The combined treatment satisfactorily met the required metals standards of marine waters and freshwaters [27].

\subsection{Challenges And Limitations Of Pervious Concrete}

Leaching of major ions and trace metals from pervious concrete associated with lower $\mathrm{pH}$ values of water: A study by Solpuker et al. [12] on the use of pervious pavements to improve the water quality of urban runoffs showed an increasing trend towards higher concentrations of major elements $(\mathrm{Ca}, \mathrm{Si}, \mathrm{Al}, \mathrm{Mg})$ and trace metals $(\mathrm{Cu}, \mathrm{Pb}$, and $\mathrm{Zn})$ associated with lower $\mathrm{pH}$ values of water. Batch experiments showed that the leachability of $\mathrm{Cu}, \mathrm{Pb}$, and $\mathrm{Zn}$ increased at $\mathrm{pH}$ of 8 . The leachability of trace metals increases under acidic conditions except for $\mathrm{Cr}$ which has high leachability only when $\mathrm{pH}=3$. This leachability of metals is mainly controlled by dissolution/precipitation and surface complexation reactions.

Clogging of pervious concrete systems: Porous concrete pavement systems are prone to clogging usually within three years after installation. Due to clogging of the voids, these systems can experience a loss of porosity. Once totally clogged, these systems have to be removed entirely and replaced. Frequent replacement renders these types of systems impractical and expensive [9]. A study by Chandrappa \& Biligiri [5] found that the clogging potential of pervious concrete decreased as the ratio of pore size to aggregate size was very large or very small. Mixes made with $4.75 \mathrm{~mm}$ aggregate (single size and binary) size had the highest potential for clogging problems due to similarities in the pore and clog material particle sizes. The top $25 \mathrm{~mm}$ of pervious concrete is mostly subjected to clogging. El-Hassan et al. [28] who examined the clogging potential of pervious concrete over a simulated lifespan of 20 years found that the rate of clogging was highest within the first 5 years and decreased over exposure time. Lower porosity concretes clogged at a faster rate than higher porosity counterparts. However, this permeability could be restored between 71 and $86 \%$ of its original value by pressurized water washing.

Long term hydraulic performance: Clogging of pervious concrete systems by organic and inorganic material reduces hydraulic conductivity, leading to low performance pervious concrete and a short lifespan of the system [2].

Elevated $\mathrm{Cr}(\mathrm{VI})$ concentration: Several studies have shown that pervious concrete contains water treatment properties and therefore offers a promising alternative treatment method for polluted or acidic mine water. However, the elevated $\mathrm{Cr}$ (VI) levels arising from the use of cement and fly ash in the concrete is a hindrance to the successful application pervious concrete in water treatment as these fail to meet the wastewater limit values applicable to discharge of wastewater into a water resource. Chromium in cement is found mainly in the form of $\mathrm{Cr}(\mathrm{III})$ and $\mathrm{Cr}(\mathrm{VI})$ and also in the form of $\mathrm{Cr}(\mathrm{IV})$ and $\mathrm{Cr}(\mathrm{V})$ in smaller amounts. Cr (VI) has been classified as a Group 1 human carcinogen by the International Agency for Research on Cancer [29] and was identified by the United States Environmental Protection Agency (US EPA) as one of the seventeen chemicals posing a threat to humans [30]. Zhao et al. [31], reported that adsorption is a promising method for eliminating chromium contaminants from water and wastewaters compared to other physical and chemical methods and has advantages like low cost, easy operation, high efficiency, and regenerative ability.

High $\mathrm{pH}$ : Shabalala et al. [13] reported that the $\mathrm{pH}$ values of acid mine drainage treated by pervious concrete increased rapidly and reached $\mathrm{pH}$ values above 12 within $24 \mathrm{~h}$. The high $\mathrm{pH}$ is attributed to the large quantities of portlandite phase in concrete that can donate hydroxide ions to the solution. When an acidic solution with a low $\mathrm{pH}$ comes in contact with cement, $\mathrm{Ca} 2+$ ions are released, alkalinity is added into the system, and $\mathrm{pH}$ increases. Acidity and high alkalinity hinders microbial growth. A pH of 6.5 to 7.5 is required for the sustenance of microbial activity and the ecosystem generally.

Limited research: Most studies have been done on the use of pervious concrete for the reduction of the stormwater runoff quantity and improvement of water quality but none or very limited studies have been done on its use in the treatment and removal of pollutants in acidic mine water, irrigation water and greywater.

Table 1. Summary of heavy metal removal by pervious concrete 


\begin{tabular}{|c|c|c|c|c|}
\hline Year & Metals treated & Removal mechanism & limitations & Author \\
\hline 2003 & $\mathrm{Cu}$ and $\mathrm{Zn}$ & & $\begin{array}{l}\text { Over a 5-year period, Zn } \\
\text { exhibited a marked } \\
\text { Increased. }\end{array}$ & $\begin{array}{l}\text { Brattebo and } \\
\text { Booth }\end{array}$ \\
\hline 2006 & $\mathrm{Cu}, \mathrm{Pb}$, and $\mathrm{Zn}$ & $\begin{array}{c}\text { High infiltration } \\
\text { capacity }\end{array}$ & $\begin{array}{l}\text { decline in infiltration rates due } \\
\text { to fine particles clogging the } \\
\text { openings in } \\
\text { the pavements. }\end{array}$ & $\begin{array}{r}\text { Gilbert and } \\
\text { Clausen }\end{array}$ \\
\hline 2011 & $\mathrm{Cu}, \mathrm{Zn}$ & $\begin{array}{c}\text { Sorption onto the } \\
\text { pervious concrete } \\
\text { pavement }\end{array}$ & & Fassman et al \\
\hline 2011 & $\mathrm{Al}, \mathrm{Ca}, \mathrm{Fe}$ and $\mathrm{Mg}$ & $\begin{array}{l}\text { Alteration of soil } \mathrm{pH} \\
\text { from moderately } \\
\text { acidic to neutral by } \\
\text { the porous } \\
\text { pavements lowers } \\
\text { mineral solubility. }\end{array}$ & Increase in $\mathrm{Na}$ and $\mathrm{K}$ & $\begin{array}{l}\text { Morgenroth } \\
\text { et al }\end{array}$ \\
\hline 2013 & $\mathrm{Fe}, \mathrm{Mn}, \mathrm{Ca}$, & $\begin{array}{l}\text { Precipitation and } \\
\text { adsorption }\end{array}$ & Increase in $\mathrm{Mg}$ & Ekolu et al. \\
\hline 2014 & $\mathrm{Cu}$ and $\mathrm{Zn}$ & $\begin{array}{l}\text { Physical capture of metals } \\
\text { in pores, surface } \\
\text { adsorption, diffusion and } \\
\text { complexation of species }\end{array}$ & & Haselbach et al. \\
\hline 2015 & $\begin{array}{l}\mathrm{Al}, \mathrm{Mn}, \mathrm{Fe}, \mathrm{Ni}, \mathrm{Cd} \\
\mathrm{Pb}, \mathrm{Zn}, \mathrm{As}, \mathrm{B}, \mathrm{V} \text { and } \\
\text { Mo }\end{array}$ & Precipitation & & Nnadi et al. \\
\hline 2016 & Fe and $\mathrm{Mn}$ & Precipitation and sorption & $\begin{array}{l}\text { Decline in the performance of } \\
\text { the PRBs after } 3 \text { years of } \\
\text { operation, with Fe removal } \\
\text { efficiency decreasing. }\end{array}$ & Wang et al. \\
\hline 2017 & $\begin{array}{l}\mathrm{Fe}, \mathrm{Al}, \mathrm{Zn}, \mathrm{Na}, \mathrm{Mn} \\
\mathrm{Mg}, \mathrm{Co}, \mathrm{Ni}\end{array}$ & $\begin{array}{l}\text { Precipitation of metal } \\
\text { hydroxides }\end{array}$ & $\begin{array}{l}\text { High } \mathrm{pH} \text { and leaching of some } \\
\text { trace elements from cement }\end{array}$ & Shabalala et al. \\
\hline 2017 & $\begin{array}{l}\mathrm{Cd}, \mathrm{Cu}, \mathrm{Ni}, \mathrm{Pb} \text {, and } \\
\mathrm{Zn} \text {, }\end{array}$ & Adsorption & & $\begin{array}{l}\text { Sounthararajah } \\
\text { et al. }\end{array}$ \\
\hline 2018 & $\begin{array}{l}\mathrm{Pb}, \mathrm{Al}, \mathrm{Fe}, \mathrm{Zn}, \mathrm{Mn} \text {, } \\
\text { and } \mathrm{Cu}\end{array}$ & adsorption and desorption & $\begin{array}{l}\text { Clogging led to poorer system } \\
\text { performance }\end{array}$ & Zhang et al. \\
\hline 2018 & $\begin{array}{l}\mathrm{Ba}, \mathrm{Cr}, \mathrm{Cd}, \mathrm{Pb}, \mathrm{As} \\
\mathrm{Al}, \mathrm{Fe}, \mathrm{Mn}, \mathrm{Cu}, \mathrm{Ni}, \\
\mathrm{Zn} \text { and } \mathrm{Sb}\end{array}$ & $\begin{array}{l}\text { adsorption, desorption, } \\
\text { filtration, physical capture } \\
\text { of metals in pores }\end{array}$ & $\begin{array}{l}\text { Leaching of } \mathrm{Cr}, \mathrm{Na}, \mathrm{K}, \mathrm{Li}, \mathrm{Si}, \mathrm{Sr} \\
\text { and } \mathrm{V} \text { from permeable } \\
\text { pavement }\end{array}$ & Liu and Borst \\
\hline
\end{tabular}




\section{Conclusion}

The review paper summarised recent literature on pervious concrete and its use in the removal of heavy metals in polluted waters. The application of porous concrete has been shown to lead to an improvement in the water quality of polluted waters. The potential use of pervious concrete for the removal of heavy metals in urban runoffs, acidic mine waters, irrigation water, and wastewater from animal production facilities was highlighted and explained with the help of case studies. Removal of metals by pervious concrete occurs through absorption, adsorption, precipitation, coprecipitation, and diffusion. Pervious concrete performance is directly related to the resulting porosity of the mixture. The high surface areas and high porosity lead to the sorption of metals on the surface of pervious concrete and the physical capture of water in the interconnected pores with subsequent precipitation. In urban runoffs, pervious concrete can function as a pollution sink, because of its particle retention capacity during filtration. Contaminants such as heavy metals are absorbed into the internal concrete body and are eliminated from the runoff. When acidic mine water is made to flow through pervious concrete, its acidity is neutralised and $\mathrm{pH}$ raised. At high $\mathrm{pH}$, most heavy metals precipitate out of solution as metal hydroxides or carbonates. The leaching of some trace metals, clogging, short lifespan, elevated $\mathrm{Cr}$ (VI) levels, high pH, and limited research were highlighted as challenges and limitations to the effective use of pervious concrete in water treatment. The potential use of pervious concrete for the removal of heavy metals present in polluted waters is a promising alternative to current treatment methods. Further work on the improvement of the pervious concrete system is needed.

\section{Acknowledgements}

The research work presented in this paper was financially supported by the National Research Foundation (NRF) of South Africa, IPRR Grant Nos.96800 and 116811. The author is grateful for the support given by NRF.

\section{References}

[1] V. López-Carrasquillo and S. Hwang, "Comparative assessment of pervious concrete mixtures containing fly ash and nanomaterials for compressive strength, physical durability, permeability, water quality performance and production cost," Constr Build Mater., vol.139, pp. 148-158, 2017.

[2] R. Zhong and K. Wille, "Material design and characterization of high performance pervious concrete," Constr Build Mater, vol. 98, pp.51-60, 2015.

[3] H. Shang and Z. Sun, "PAHs (naphthalene) removal from stormwater runoff by organoclay amended pervious concrete," Constr Build Mater, vol. 200, pp. 170-180, 2019.

[4] Y. Zaetang, A. Wongsa, V. Sata and P. Chindaprasirt, "Use of coal ash as geopolymer binder and coarse aggregate in pervious concrete," Constr Build Mater, vol. 96, pp. 289-295, 2015.

[5] A.K. Chandrappa, and K.P. Biligiri K.P, "pervious concrete as a sustainable pavement material - Research findings and future prospects: A state-of-the-art review," Constr Build Mater, vol. 111, pp. 262-274, 2016.

[6] N. Xie, M. Akin and X. Shi X, "Permeable concrete pavements: A review of environmental benefits and durability," $J$ Clean Prod., vol. 210, pp. 1605-1621, 2019.

[7] B.O. Brattebo and D.B. Booth, "Long-term stormwater quantity and quality performance of permeable pavement systems," Water Res., vol. 37, pp. 4369-4376, 2003.

[8] A. Yousefi and S. Matavos-Aramyan, "Mix design optimization of silica fume-based pervious concrete for removal of heavy metals from wastewaters," Silicon, vol. 10, pp. 1737-1744, 2018.

[9] M. Scholz, and P. Grabowiecki, "Review of permeable pavement systems," Build Environ. vol. 42, pp. 3830- 3836, 2007.

[10] S.O. Ekolu, F.Z. Azene and S. Diop, "A concrete reactive barrier for acid mine drainage treatment," Proceedings of Institute of Civil Engineering, Water Manag, vol. 167, pp. 373-380, 2013.

[11] S.O. Ekolu, F.Z. Azene and S. Diop, "A concrete reactive barrier for acid mine drainage treatment," Proceedings of the Institution of Civil Engineers, Water Manage. vol.167, pp.373-380, 2014.

[12] U. Solpuker, J. Sheets, Y. Kim and F.W. Schwartz, "Leaching potential of pervious concrete and immobilization of $\mathrm{Cu}, \mathrm{Pb}$ and $\mathrm{Zn}$ using pervious concrete," J Contam Hydrol., vol. 161, pp. 35-48, 2014.

[13] A.N. Shabalala, S.O. Ekolu, S. Diop and F. Solomon, "Pervious concrete reactive barrier for removal of heavy metals from acid mine drainage - column study," J Hazard Mater., vol. 323, pp. 641-653, 2017. 
[14] K. Zhang, F. Yong and D.T. McCarthy, A. Deletic, "Predicting long term removal of heavy metals from porous pavements for stormwater treatment," Water Res. Vol. 142, pp. 236-245, 2018.

[15] F.O. Nnadi, A.P. Newman, S.J. Coupe and F.U. Mbanaso, "Stormwater harvesting for irrigation purposes: An investigation of chemical quality of water recycled in pervious pavement system," J Environ Manage., vol. 147, pp. 246-256, 2015.

[16] M. Lee, M. Lee, Y. Huang and C. Chiang, "Purification Study of Pervious Concrete Pavement," IACSIT Int J Eng Technol., vol. 5, pp. 532-535, 2013.

[17] J.D. Luck, S.R. Workman, M.S. Coyne and S.F. Higgins S.F, "Solid material retention and nutrient reduction properties of pervious concrete mixtures," Biosyst Eng., vol. 100, pp. 401-408, 2008.

[18] L. Haselbach, C. Poor and J. Tilson, "Dissolved zinc and copper retention from stormwater runoff in ordinary portland cement pervious concrete," Constr Build Mater., vol. 53, pp. 652-657, 2014.

[19] R.R. Holmes, M.L. Hart, J.T. Kevern, "Heavy metal removal capacity of individual components of permeable reactive concrete," J Contam Hydrol., vol.196, pp. 52-61, 2017.

[20] M.G. Sephton and J.A. Webb, "The role of secondary minerals in remediation of acid mine drainage by Portland cement," J Hazard Mater., vol.367, pp. 267-276, 2019.

[21] E.Z. Bean, W.F. Hunt, and D.A. Bidelspach, "Evaluation of four permeable pavement sites in eastern North Carolina for runoff reduction and water quality impacts," J. Irrig Drain Eng., vol.133(6), pp. 583-592, 2007.

[22] J. Liu and M. Borst, "Performances of metal concentrations from three permeable pavement infiltrates," Water Res., vol. 136, pp. 41-53, 2018.

[23] J.K. Gilbert, J.C. Clausen, "Stormwater runoff quality and quantity from asphalt, paver, and crushed stone driveways in Connecticut," Water Res., vol. 40, pp. 826 - 832, 2006.

[24] E.A. Fassman, S.D. Blackbourn, "Road runoff water-quality mitigation by permeable modular concrete pavers," J. Irrig Drain Eng., vol 137, pp. 720-729, 2011.

[25] J. Morgenroth, G. Buchan, B.C. Scharenbroch, "Belowground effects of porous pavements - soil moisture and chemical properties," Ecol Eng., vol 51, pp. 221- 228, 2013.

[26] Y. Wang, S. Pleasant, P. Jain, J. Powell, T. Townsend, "Calcium carbonate-based permeable reactive barriers for iron and manganese groundwater remediation at landfills," Waste Manage., vol. 53, pp. 128 -135, 2016.

[27] D.P. Sounthararajah, P. Loganathan, J. Kandasamy and S. Vigneswaran, "Removing heavy metals using permeable pavement system with a titanate nano-fibrous adsorbent column as a post treatment," Chemosphere, vol. 168, pp. 467473, 2017.

[28] H. El-Hassan, P. Kianmehr and S. Zouaoui, "Properties of pervious concrete incorporating recycled concrete aggregates and slag", Constr Build Mater., vol. 212, pp. 164-175.

[29] International Agency for Research on Cancer (IARC), IARC Monographs of the Evaluation of the Carcinogenic Risk of Chemicals to Humans: Chromium, Nickel and Welding. Lyon: IARC, 1990.

[30] R. Jobby, P. Jha, A.K. Yadav and N. Desai, "Biosorption and biotransformation of hexavalent chromium [Cr(VI)]: A comprehensive review", Chemosphere, vol. 207, pp. 255 - 266, 2018.

[31] Y. Zhao, W. Qi, G. Chen, M. Ji M and Z. Zhang, "Behavior of Cr(VI) removal from wastewater by adsorption onto $\mathrm{HCl}$ activated Akadama clay," J Taiwan Inst Chem Eng., vol. 50, pp. 190 -197, 2015. 